\title{
Do Midwifes Represent Risk of "Stealing" Patients from OBG Physicians? Not in Low and Middle-income System
}

\author{
D. Kalatova (Dagmar Kalatova)', M. Luliak (Milan Luliak)², D. West (Daniel West)³, \\ V. Krcmery (Vladimir Krcmery)4,5, N. Jalili (Nasir Jalilii) ${ }^{5,6}$, M. Olah (Michal Olah)7,8, \\ L. Matulnikova (Ludmila Matulnikova) ${ }^{7}$ M. Palun (Miroslav Palun) ${ }^{9}$
}

1 Institute of Jan Nepomuk Neumann, St. Elizabeth Univ, Pribram, Original Article Czech Republic.

2 Refugee Camp UNHCRAlexandia, Refugee and Migrant Centre Lesbos, Greece.

${ }^{3}$ Univ of Scranton Panuska School of Professional Studies, PA, USA.

${ }^{4}$ Global health Program of St. Elizabeth Univ. \& St. Eesley College N Zamky, Slovakia.

${ }^{5}$ Inst. of Microbiology, School of Medicine Commenius University, Bratislava, Slovakia

${ }^{6}$ Nasir Ahmed Jalili Foundation Elementary and Secondary School at Mazare Sharif, Afganistan

7 St. Elizabeth University of Health and Social Work in Bratislava, Slovakia.

8 The PRIGO University, Havirov, Czech Republic.

9 St. Elizabeth University of Health and Social Work in Bratislava, Institute Dr. Pavol Blaha, Skalica, Slovakia.

\section{E-mail address:}

tropicteam@gmail.com

\section{Reprint address:}

Ludmila Matulnikova

St. Lesley College

Nove Zamky

Slovakia

Source: Clinical Social Work and Health Intervention

Pages: $24-26$

\section{Reviewers:}

Vlastimil Kozon

University Hospital, Vienna, AT

Daria Kimuli

St. Philippe Neri School, Joshka Nairobi, KE

\section{Keywords:}

Patients. OBG Physicians. Middle-income System.
Volume: $10 \quad$ Issue: 3

Cited references: 4 


\section{Publisher:}

International Society of Applied Preventive Medicine i-gap

CSWHI 2019; 10(2): 24 - 26; DOI: 10.22359/cswhi_10_3_07 @ 2019 Clinical Social Work and Health Intervention

\section{Abstract:}

Several new paramedical disciplines has been introduced in new EU member states within the last 20 years, such as midwifery, nursing, physiotherapy, dental technician etc. and concern was observed in discussions if those disciplines are not replacing qualified physicians such as $\mathrm{OBG}$, neurologists, dental surgeons. Another concern was published when critically assessing their curricula during national accreditation processes.

\section{Global Health Environment}

Starting with midwifery, more than half of WHO member states had midwifery organically included in their health system. After World War II, Europe, Ukraine and Russia have had excellent experience with so called Feldsherr-Acoucher Specialists originating from French and German military experience in late $18^{\text {th }}$ and $19^{\text {th }}$ centuries. Those specialists were active and competent, especially in areas of weak healthcare infrastructure and were more than capable in deliveries countrywide in the last 70 years. The study programs still exist in many Eastern European universities.

Outside of Europe, apart of Latin America, midwifery in Africa and Asia is traditionally a capable discipline to achieve at least two of the millennium goals: to decrease neonatal and decrease maternal mortality in developing countries.

For example, in Ethiopia, every midwife is able to perform caesarean section after 3 years of training. Within last 50 years, this second highest population country in Africa has substantially decreased maternal and neonatal mortality.

\section{Conclusions}

Jealousy of physicians including OBG doctors in the EU is understandable due to historic and logistic fact of sufficient number of doctors, but is no longer tolerable. First, we can still see countries in Europe and outside of the EU e.g. Bosnia \& Herzegovina, Moldova, Albania, approaching the EU but having unacceptable high neonatal and maternal mortality rates. Second, due to low numbers of OBG specialists in Sub-Saharan Africa and Southeast Asia, midwifery professionals are our only hope in the everlasting battle against neonatal and maternal mortality worldwide.

\section{References}

1. WHO 2015 Annual report, Geneve WHO, CH, ISBN 1332565525, 2015, 450 pp.

2. GARDIANOVA I, BARTONOVA A (2018) Use of guinea pig as zoo rehabilitation animals-caviatherapy, Rehabilitacia Vol. 55, no. 1, ISSN0375-0922, pp. 41-49.

3. ACOVA Et Al. (2016) Pope Francis' Trends in the Social Teaching of the Catholic Church. Bratislava. ISBN 97880-89413-86-7. 
4. CEPOVA E, KOLARCIK P, MADARASOVA GECKOVA A (2017) Health literacy, a method to improve the health of the population and its use in public health In: Health and Social Work. ISSN 133369326. Vol. 12, No 1, p. 25-33. 